A book, and especially one's first book, would not be possible without the assistance of countless individuals. Many individuals helped give shape to this work. I would like to thank Greg Kennedy, Geraint Hughes, Jeffrey Michaels, Anatol Lieven, and Patrick Porter at King's College London and Fredrik Logevall, Steven Miller, and Steve Walt for their input at the Harvard Kennedy School. Anne Miles, Brian Shaev, and Oliver Elliott read sections of the manuscript and provided valuable food for thought. I also wish to thank the staff of Cornell University Press, and especially Michael McGandy, for believing in this project and helping to see it to fruition. Several passages from chapters 1,3 , and 7 were previously published in the Journal of Cold War Studies.

The students and staff of the Joint Services Command and Staff College at Shrivenham shared with me their own experiences of nation building and counterinsurgency and pushed me to engage with the realities of these theoretical concepts. Quite against the intention of the British taxpayers who funded my time as a teaching fellow there, I think it was I who learned more from them.

I was fortunate enough to present this work at conferences and seminars, including those of the MIT Security Studies Program, the Society of Historians of American Foreign Relations, the Sir Michael Howard Seminar at King's College London, the Transatlantic Studies Association, the Canadian Historical Association, the Texas Tech Vietnam War Center and Archive, and the Harvard Belfer Center's International Security Program. On each occasion I received valuable feedback, and I would like to thank the organizers and convenors for making these presentations possible.

Grants from the Lyndon Johnson Foundation and from King's College London made research trips possible. Special thanks go to the staff of each of the archives I visited, especially those who had to wade through my hundreds of declassification requests. Outside the archive, Douglas C. Dacy provided me with a valuable trove of research materials, which considerably shaped the direction of my research.

Thanks are also due to my parents, who have supported me in ways that only they will ever know.

None of this would have been possible without the loving support of my wife, Janice, with whom I share this journey of discovery through life, along with, in 
the words of Arendt, an intense "wonder at what is as it is" in the world. I could truly ask for no better companion along the way. Credit for finding the images used in the book is also due to her.

Having received such abundant assistance, I can only conclude by noting that whatever errors or omissions remain could do so only through some fault of my own. 


\section{TO BUILD AS WELL AS DESTROY}


